\title{
SPECIFIC BRAIN DELIVERY OF PYRIDYL CHLOROETHYLUREA DERIVATIVES AS POTENTIAL ANTITUMOR AGENTS: SYNTHESIS, EVALUATION AND MOLECULAR MODELING STUDY
}

\author{
Nawal A. El-Koussi \\ Department of Medicinal Chemistry, Faculty of Pharmacy, Assiut University, Assiut, Egypt

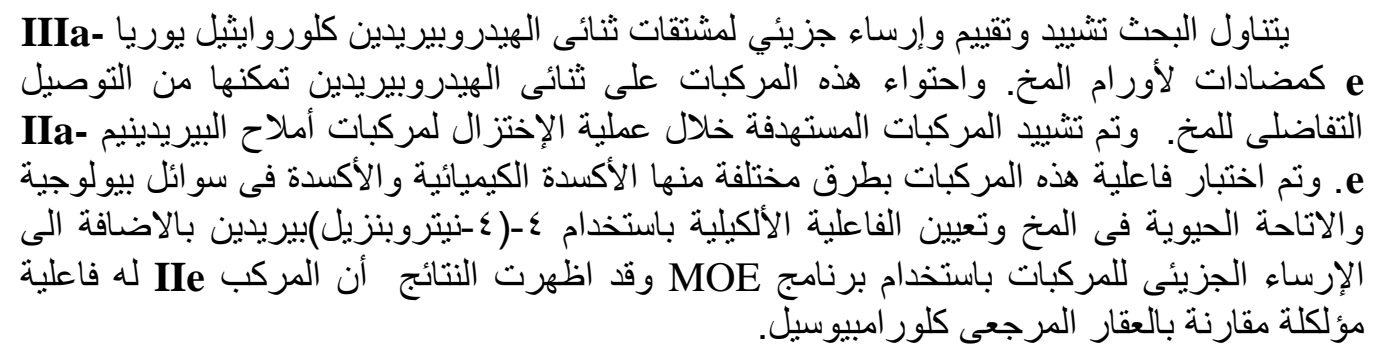

The present investigation describes the synthesis; evaluation and molecular modeling studies of a series of 1-substituted-1,4-dihydropyridine-3-chloroethylurea derivatives IIIa-e as potential agents for treatment of brain tumors. The incorporation of the 1,4-dihydropyridine moiety in the structure attains an efficient site specific chemical delivery system (CDS) of the chloroethylurea (CEU) as a known antitumor pharmacophore to the brain. The target compounds IIIa-e were synthesized through reduction of the corresponding quaternary compounds IIa-e. The in-vitro oxidation studies showed that, compounds IIIa-e could be oxidized into their corresponding quaternary compounds IIa-e, respectively which attains their "locked in" characteristics as brain antitumor agents. The in-vivo studies showed that compound III a was able to cross the BBB at detectable concentration. In addition the in-vitro alkylating activity studies using 4-(4-nitrobenzyl)pyridine (NBP) revealed that compound IIe is an efficient alkylating agent with activity comparable to reference drug chlorambucil. The target compounds were tested for their binding to the colchicine-binding site (CBS) of $\beta$-tubulin using Molecular Operating Environment (MOE) software.

\section{INTRODUCTION}

Brain tumors are one of the most lethal forms of cancer, that are extremely difficult to treat. Clinical failure of several potentially effective therapeutics for the treatment of brain tumors is usually not due to a lack of drug potency, but rather can be attributed to shortcomings in the delivery of a drug to the brain. Extensive efforts have been made to develop novel strategies to overcome such obstacles.

The use of dihydropyridine / pyridinium redox carrier as brain-specific chemical delivery system $(\mathrm{CDS})^{1-3}$ provides an important flexible method and sustained delivery of drugs to the brain. In-vivo the lipohillic characteristics of the dihydropyridine affects the transport of the drug into the brain. Meanwhile, enzymatic oxidation of the carrier moiety to the quaternary pyridinium inside the brain hinders rapid elimination affording a means for sustained effect "locked in" and accelerate its clearance from the peripheral circulation and subsequently reduce the possible side effects of the parent drug ${ }^{4-7}$.

Substituted phenyl chloroethylureas were designed whereby affording a combination of the known antitumor agent chlorambucil and the unnitrosated pharmacophore of carmustine to give more active compounds than chlorambucil and carmustine ${ }^{8-11}$. Moreover, the lipophillic 1,4-dihydropyridine moiety attains a good mean for site specific delivery to the 
brain. Incorporation of alkyl or substituted benzyl to N-1 of the 1,4-dihydropyridine moiety provides targeting in a manner similar to that of $\mathrm{CDSs}^{8}$.

Interestingly, Chloroethylureas (CEUs) mediate their cytotoxicity by covalent binding to cell proteins, and the main alkylated protein for antimitotic CEUs is $\beta$-tubulin ${ }^{12}$. The electrophilic 2-chloroethylamino moiety of the molecule was initially proposed to interfere with the cysteinyl-239 residue of human $\beta$ tubulin $^{12}$, whereas the migrational modification of $\beta$-tubulin following treatment with antimitotic CEUs was shown to be related to the esterification of glutamic acid-198 of mouse $\beta$-tubulin ${ }^{13}$, located near the colchicinebinding site ${ }^{14}$. This modification blocks the entry of tubulin in the mitotic spindle or destabilizes it, leading to a $\mathrm{G}_{2} / \mathrm{M}$ cell-cycle arrest.

These observations prompted us to synthesize a new series of pyridylchloroethylurea derivatives, studing their alkylating activity chemically using NBP and investigating the molecular modeling characteristics to the colchicine-binding site of $\beta$-tubulin using MOE.

\section{EXPERIMENTAL}

Melting points were determined in open glass capillaries and are uncorrected. UV spectra were recorded on Pye Unicam SP 1750 UV/Vis Spectrophotometer. ${ }^{1} \mathrm{H}-\mathrm{NMR}$ spectra were recorded on a $60 \mathrm{MHz}$ EM-390 spectrometer in DMSO- $\mathrm{d}_{6}$ and TMS as internal standard. Chemical shifts are expressed in $\delta$ ppm, and coupling constant $(\mathrm{J})$ are given in $\mathrm{Hz}$. Elemental analyses for $\mathrm{C}, \mathrm{H}$, and $\mathrm{N}$ were performed at the unit of microanalysis, Cairo University. Thin-layer chromatography was performed on precoated $(0.25 \mathrm{~mm}, 60 \mathrm{~F} 254)$ silica gel plates, compounds were detected with a 254-nm UV lamp. The HPLC system consisted of a Knauer model 64 solvent delivery module (Knauer, Germany), a Knauer variable wave length $\mathrm{UV}$ detector at $20 \mu \mathrm{L}$ sample loop, and Shimadzu CR-6A chromatopac integrator (Shimadzu, Tokyo, Japan). The column used was a Knauer C18 $(250 \mathrm{~mm} \times 4.6 \mathrm{~mm} \mathrm{ID}, 5 \mu \mathrm{m})$. The effluent monitored at $262 \mathrm{~nm}$ at flow rate $1.5 \mathrm{~mL} / \mathrm{min}$.
The mobile phase used consisted of $10 \%$ acetonitrile in $0.2 \%$ acetic acid.

\section{Synthesis of 1-(2-chloroethyl)-3-pyridin-3- yl-urea $I^{15}$}

A stirred solution of 3-aminopyridine (39 $\mathrm{mmol})$ in THF (50 mL) was treated dropwise at $0-5^{\circ} \mathrm{C}$ with 2-chloroethylisocyanate $(39 \mathrm{mmol})$ in THF $(10 \mathrm{~mL})$. The reaction mixture was stirring at room temperature for $1.5 \mathrm{hrs}$. The solvent was removed under reduced pressure and the product was crystallized from ethyl acetate. Yield (80\%), m.p. $137-8^{\circ} \mathrm{C}$.

General procedure for preparation of 1alkyl(4-substituted benzyl)-3-[3-(2-chloroethyl)ureido]pyridinium halides IIa-e

To a solution of compound $\mathbf{I}(10 \mathrm{mmol})$ in ethanol $(30 \mathrm{~mL})$, appropriate alkyl or substituted benzyl halide $(15 \mathrm{mmol})$ in ethanol $(10 \mathrm{~mL})$ was added with stirring, the mixture was refluxed 8-10 hrs. Solvent was removed under reduced pressure and the obtained residue was triturated with ether till solidification. The obtained solid was crystallized from ethanol to give IIa-e.

\section{3-[3-(2-Chloroethyl)ureido]-1-methyl- pyridinium iodide IIa}

Yield (65\%), m.p. $166-167^{\circ} \mathrm{C}$. IR (KBr) v: 3345, $3225(\mathrm{NH}), 1688(\mathrm{C}=\mathrm{O}) \mathrm{Cm}^{-1} .{ }^{1} \mathrm{H}-\mathrm{NMR}$ $\left(\right.$ DMSO-d $\left._{6}\right) \delta(\mathrm{ppm}): 3.47(\mathrm{t}, \mathrm{J}=6.1 \mathrm{~Hz}, 2 \mathrm{H}$, $\left.\mathrm{CH}_{2} \mathrm{CH}_{2} \mathrm{Cl}\right), \quad 3.69$ (t, J= $6.0 \mathrm{~Hz}, \quad 2 \mathrm{H}$, $\left.\mathrm{CH}_{2} \mathrm{CH}_{2} \mathrm{Cl}\right), 4.33\left(\mathrm{~s}, 3 \mathrm{H}, \mathrm{N}^{+} \mathrm{CH}_{3}\right), 6.93(\mathrm{~s}, 1 \mathrm{H}$, $\left.\mathrm{NHCH}_{2} \mathrm{CH}_{2}\right), 7.80-8.40(\mathrm{~m}, 2 \mathrm{H}, \mathrm{C} 4-$ and $\mathrm{C} 5-$ pyr.), 8.56 (d, J= $7 \mathrm{~Hz}, 1 \mathrm{H}, \mathrm{C6}-$ pyr.), 9.10 (s, 1H, C2-pyr.), 9.73 (s, 1H, NHCO).

Anal. $\left(\mathrm{C}_{9} \mathrm{H}_{13} \mathrm{ClIN}_{3} \mathrm{O}\right)$ (Cald/ Found) C, 31.62/31.20; H, 3.80/3.60; N 12.30/12.00).

\section{3-[3-(2-Chloroethyl)ureido]-1-ethylpyridin- ium iodide IIb}

Yield (60\%), m.p. $147-8^{\circ} \mathrm{C}$. IR (KBr) v $\mathrm{cm}^{-1}$ : 3345, $3225(\mathrm{NH}), 1670(\mathrm{C}=\mathrm{O}){ }^{1} \mathrm{H}-\mathrm{NMR}$ $\left(\right.$ DMSO-d $\left._{6}\right) \delta(\mathrm{ppm}): 1.60(\mathrm{t}, \mathrm{J}=7.0 \mathrm{~Hz}, 3 \mathrm{H}$, $\left.\mathrm{CH}_{2} \mathrm{CH}_{3}\right), 3.45\left(\mathrm{t}, \mathrm{J}=6.0 \mathrm{~Hz}, 2 \mathrm{H}, \mathrm{CH}_{2} \mathrm{CH}_{2} \mathrm{Cl}\right.$ ), $3.65\left(\mathrm{t}, \mathrm{J}=6.0 \mathrm{~Hz}, 2 \mathrm{H}, \mathrm{CH}_{2} \mathrm{CH}_{2} \mathrm{Cl}\right), 4.70$ (q, J= $\left.7.0 \mathrm{~Hz}, \quad 2 \mathrm{H}, \quad \mathrm{N}^{+} \mathrm{CH}_{2} \mathrm{CH}_{3}\right) ; 6.95 \quad(\mathrm{~s}, \quad 1 \mathrm{H}$, $\left.\mathrm{NHCH}_{2} \mathrm{CH}_{2}\right), 7.80-8.50(\mathrm{~m}, 2 \mathrm{H}, \mathrm{C} 4-$ and $\mathrm{C} 5-$ pyr.), 8.73 (d, J=7.0 Hz, 1H, C6-pyr.), 9.30 (s, 1H, C2-pyr.), 9.80 (s, 1H, NHCO).

Anal. $\left(\mathrm{C}_{10} \mathrm{H}_{15} \mathrm{ClIN}_{3} \mathrm{O}\right)$ (Cald/ Found) $\mathrm{C}$, 33.75/33.50; H, 4.21/4.00; N, 11.61/11.50). 
1-(4-Chlorobenzyl)-3-[3-(2-chloroethyl)ureido]pyridinium chloride IIc

Yield (90\%), m.p. $186-7^{\circ} \mathrm{C}$. IR ( $\left.\mathrm{KBr}\right) v$ $\mathrm{cm}^{-1}$ : 3340, $3225(\mathrm{NH}), 1680(\mathrm{C}=\mathrm{O}){ }^{1} \mathrm{H}-\mathrm{NMR}$ $\left(\right.$ DMSO-d $\left._{6}\right) \delta(\mathrm{ppm}): 3.48(\mathrm{t}, \mathrm{J}=6.0 \mathrm{~Hz}, 2 \mathrm{H}$, $\left.\mathrm{CH}_{2} \mathrm{CH}_{2} \mathrm{Cl}\right) . \quad 3.70 \quad(\mathrm{t}, \quad \mathrm{J}=6.0 \mathrm{~Hz}, 2 \mathrm{H}$, $\mathrm{CH}_{2} \mathrm{CH}_{2} \mathrm{Cl}$ ), 6.10 (s, $\left.2 \mathrm{H}, \mathrm{N}^{+} \mathrm{CH}_{2}\right), 7.50(\mathrm{~s}, 1 \mathrm{H}$, $\mathrm{NHCH}_{2} \mathrm{CH}_{2}$ ), 7.60-8.30 (m, 5H, C5-pyr., 4 $\mathrm{ArH}), 8.56$ (d, J=7.0 Hz, 1H, C4-pyr.), 9.06 (d, $\mathrm{J}=7.0 \mathrm{~Hz}, 1 \mathrm{H}, \mathrm{C} 6$-pyr.), 9.63 (s, 1H, C2-pyr.), 10.10 (s, 1H, NHCO).

Anal. $\left(\mathrm{C}_{15} \mathrm{H}_{16} \mathrm{Cl}_{3} \mathrm{~N}_{3} \mathrm{O}\right)$ (Cald / Found) $\mathrm{C}$, 49.93/49.70; H, 4.44/4.20; N, 11.65/11.40.

\section{1-(4-Bromobenzyl)-3-[3-(2-chloroethyl)- ureido]pyridinium bromide IId}

Yield (75\%), m.p. $190-191^{\circ} \mathrm{C}$. IR (KBr) v $\mathrm{cm}^{-1}$ : 3340, $3225(\mathrm{NH}), 1688(\mathrm{C}=\mathrm{O}) .{ }^{1} \mathrm{H}-\mathrm{NMR}$ $\left(\right.$ DMSO-d $\left._{6}\right) \delta(\mathrm{ppm}): 3.45(\mathrm{t}, \mathrm{J}=6.0 \mathrm{~Hz}, 2 \mathrm{H}$, $\left.\mathrm{CH}_{2} \mathrm{CH}_{2} \mathrm{Cl}\right), 3.68$ (t, J= $6.1 \mathrm{~Hz}, \quad 2 \mathrm{H}$, $\left.\mathrm{CH}_{2} \underline{\mathrm{CH}}_{2} \mathrm{Cl}\right), 5.93\left(\mathrm{~s}, 2 \mathrm{H}, \mathrm{N}^{+} \underline{\mathrm{CH}}_{2}\right), 7.10(\mathrm{~s}, 1 \mathrm{H}$, $\left.\mathrm{NH} \mathrm{CH}_{2} \mathrm{CH}_{2}\right), 7.33-7.83(\mathrm{~m}, 4 \mathrm{H}, \mathrm{ArH}), 7.70-$ 8.53 (m, 2H, C4- and C5-pyr.), 8.86 (d, J=7.0 Hz, 1H, C6-pyr.), 9.43 (s, 1H, C2-pyr.), 10.20 (s, $1 \mathrm{H}, \underline{\mathrm{NHCO}}$ ).

Anal. $\left(\mathrm{C}_{15} \mathrm{H}_{16} \mathrm{Br}_{2} \mathrm{ClN}_{3} \mathrm{O}\right)$ (Cald/Found) $\mathrm{C}$, 40.04/39.80; H, 3.55/3.50; N, 9.34/9.10).

\section{3-[3-(2-Chloroethyl)ureido]-1-(4-nitro- benzyl)pyridinium bromide IIe}

Yield (88\%), m.p. $210-12^{\circ} \mathrm{C}$. IR (KBr) $v$ $\mathrm{cm}^{-1}$ : 3387, $3265(\mathrm{NH}), 1693(\mathrm{C}=\mathrm{O}), 1564$, $1354(\mathrm{~N}=\mathrm{O}) .{ }^{1} \mathrm{H}-\mathrm{NMR}\left(\mathrm{DMSO}^{\left.-\mathrm{d}_{6}\right)} \delta(\mathrm{ppm})\right.$ : 3.44 (t, J=6.0 Hz, 2H, $\left.\mathrm{CH}_{2} \mathrm{CH}_{2} \mathrm{Cl}\right) .3 .67$ (t, J= $\left.6.0 \mathrm{~Hz}, 2 \mathrm{H}, \mathrm{CH}_{2} \mathrm{CH}_{2} \mathrm{Cl}\right), 6.13\left(\mathrm{~s}, 2 \mathrm{H}, \mathrm{N}^{+} \mathrm{CH}_{2}\right)$, $7.10\left(\mathrm{~s}, 1 \mathrm{H}, \mathrm{NHCH}_{2} \mathrm{CH}_{2}\right), 7.80(\mathrm{~d}, \mathrm{~J}=7.0 \mathrm{~Hz}$, 2H, ArH), 8.10-8.20 (m, 2H, C4-,C5-pyr.), 8.30 $(\mathrm{d}, \mathrm{J}=7.0 \mathrm{~Hz}, 2 \mathrm{H}, \mathrm{ArH}), 8.90(\mathrm{~d}, \mathrm{~J}=7.5 \mathrm{~Hz}$, 1H, C6-pyr.), 9.50 (s, 1H, C2-pyr.), 10.26 (s, $1 \mathrm{H}, \mathrm{NHCO})$.

Anal. $\left(\mathrm{C}_{15} \mathrm{H}_{16} \mathrm{BrClN}_{4} \mathrm{O}_{3}\right)$ (Cald/ Found) $\mathrm{C}$, 43.32/43.10; H, 3.85/3.60; N, 13.47/13.40).

\section{General procedure for preparation of 1-(2-chloroethyl)-3-[1-alkyl(4-substituted benzyl)-1,4-dihydropyridin-3-yl]ureas IIIa-e \\ To a suspension of 1-alkyl (4-substituted benzyl)-3-[3-(2-chloroethyl) ureido]pyridinium halides IIa-e $(10 \mathrm{mmol})$ in degassed water (100 $\mathrm{mL})$ and methylene chloride $(25 \mathrm{~mL})$ previously cooled to $0^{\circ} \mathrm{C}$ and stirred under nitrogen stream, sodium bicarbonate $(60 \mathrm{mmol})$}

was added portionwise over a period of $15 \mathrm{~min}$. Sodium dithionite $(40 \mathrm{mmol})$ was then added portionwise over 10 minutes. Stirring was continued under nitrogen stream at $0^{\circ} \mathrm{C}$ for 2 hrs. The reaction mixture was extracted with three portions of methylene chloride. The extract was washed with cold deaereated water, dried with anhydrous sodium sulfate and evaporated in vacuo to give the crude dihydropyridyl compounds IIIa-e.

\section{1-(2-Chloroethyl)-3-[1-methyl-1,4-dihydro- pyridin-3-yl]urea IIIa}

Yield (55\%, oily). ${ }^{1} \mathrm{H}-\mathrm{NMR}\left(\mathrm{CDCl}_{3}\right) \delta$ (ppm): 2.9 (s, 3H, N-CH ${ }_{3}$ ). 3.0-3.2 (m, 2H, C4$\mathrm{H}), 3.42\left(\mathrm{t}, \mathrm{J}=6.0 \mathrm{~Hz}, 2 \mathrm{H}, \mathrm{CH}_{2} \mathrm{CH}_{2} \mathrm{Cl}\right), 3.63(\mathrm{t}$, $\left.\mathrm{J}=6.0 \mathrm{~Hz}, 2 \mathrm{H}, \mathrm{CH}_{2} \mathrm{CH}_{2} \mathrm{Cl}\right), 4.78(\mathrm{~m}, 1 \mathrm{H}, \mathrm{C} 5-$ $\mathrm{H}), 5.53(\mathrm{~s}, 1 \mathrm{H}, \mathrm{C} 6-\mathrm{H}), 6.76-6.90(\mathrm{~s}, 1 \mathrm{H}$, $\left.\mathrm{NHCH}_{2} \mathrm{CH}_{2}\right), 7.1(\mathrm{~s}, 1 \mathrm{H}, \mathrm{C} 2-\mathrm{H}), 9.64(\mathrm{~s}, 1 \mathrm{H}$, NHCO).

\section{1-(2-Chloroethyl)-3-[1-ethyl-1,4-dihydro- pyridin-3-yl]urea IIIb}

Yield $\left(52 \%\right.$, oily). ${ }^{1} \mathrm{H}-\mathrm{NMR}\left(\mathrm{CDCl}_{3}\right) \delta$ (ppm): 1.3 (t, J= 7.0 Hz, 3H, N-CH $\mathrm{CH}_{3}$ ), 3.0$3.2(\mathrm{~m}, 2 \mathrm{H}, \mathrm{C} 4-\mathrm{H}), 3.4(\mathrm{t}, \mathrm{J}=6.0 \mathrm{~Hz}, 2 \mathrm{H}$, $\left.\mathrm{CH}_{2} \mathrm{CH}_{2} \mathrm{Cl}\right), 3.65$ (t, J= $6.0 \mathrm{~Hz}, 2 \mathrm{H}$, $\mathrm{CH}_{2} \mathrm{CH}_{2} \mathrm{Cl}$ ), 4.6 (q, J= $7.0 \mathrm{~Hz}, 2 \mathrm{H}, \mathrm{N}-\mathrm{CH}_{2} \mathrm{CH}_{3}$ ), 4.70 (m, 1H, C5-H), 5.57 (s, 1H, C6-H), 6.76$6.90\left(\mathrm{~s}, 1 \mathrm{H}, \mathrm{NHCH}_{2} \mathrm{CH}_{2}\right), 7.2(\mathrm{~s}, 1 \mathrm{H}, \mathrm{C} 2-\mathrm{H})$, $9.64(\mathrm{~s}, 1 \mathrm{H}, \mathrm{NHCO})$.

\section{1-[1-(4-Chlorobenzyl)-1,4-dihydropyridin-3-} yl]-3-(2-chloroethyl)urea IIIc

Yield $\left(54 \%\right.$, oily); ${ }^{1} \mathrm{H}-\mathrm{NMR}\left(\mathrm{CDCl}_{3}\right) \delta$ (ppm): 3.0-3.2 (m, 2H, C4-H). 3.45 (t, J=6.0 $\left.\mathrm{Hz}, 2 \mathrm{H}, \mathrm{CH}_{2} \mathrm{CH}_{2} \mathrm{Cl}\right), 3.65(\mathrm{t}, \mathrm{J}=6.0 \mathrm{~Hz}, 2 \mathrm{H}$, $\left.\mathrm{CH}_{2} \mathrm{CH}_{2} \mathrm{Cl}\right), 4.70(\mathrm{~m}, 1 \mathrm{H}, \mathrm{C} 5-\mathrm{H}), 5.57(\mathrm{~m}, 3 \mathrm{H}$,

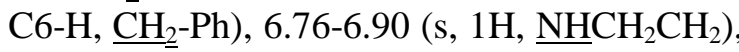
$7.2(\mathrm{~s}, 1 \mathrm{H}, \mathrm{C} 2-\mathrm{H}), 7.52-7.30(\mathrm{dd}, \mathrm{J}=7.0 \mathrm{~Hz}$, $4 \mathrm{H}, \mathrm{ArH}), 10.9$ (s, 1H, NHCO).

\section{1-[1-(4-Bromobenzyl)-1,4-dihydropyridin-3-} yl]-3-(2-chloroethyl)urea IIId

Yield $\left(51 \%\right.$, oily); ${ }^{1} \mathrm{H}-\mathrm{NMR}\left(\mathrm{CDCl}_{3}\right) \delta$ (ppm): 2.80-3.0 (m, 2H, C4-H). 3.44 (t, J=6.0 $\left.\mathrm{Hz}, 2 \mathrm{H}, \mathrm{CH}_{2} \mathrm{CH}_{2} \mathrm{Cl}\right), 3.66(\mathrm{t}, \mathrm{J}=6.0 \mathrm{~Hz}, 2 \mathrm{H}$, $\left.\mathrm{CH}_{2} \mathrm{CH}_{2} \mathrm{Cl}\right), 4.60(\mathrm{~m}, 1 \mathrm{H}, \mathrm{C} 5-\mathrm{H}), 5.57(\mathrm{~m}, 3 \mathrm{H}$, C6-H, $\underline{\mathrm{CH}}_{2}-\mathrm{Ph}$ ), 6.76-6.80 (s, 1H, $\mathrm{NHCH}_{2} \mathrm{CH}_{2}$ ), $7.1(\mathrm{~s}, 1 \mathrm{H}, \mathrm{C} 2-\mathrm{H}), 7.33-7.83(\mathrm{dd}, \mathrm{J}=8.5 \mathrm{~Hz}$, $4 \mathrm{H}, \mathrm{ArH}), 10.20$ (s, 1H, NHCO). 
1-(2-Chloroethyl)-3-[1-(4-nitrobenzyl)-1,4dihydropyridin-3-yl]urea IIIe

Yield $\left(50 \%\right.$, oily); ${ }^{1} \mathrm{H}-\mathrm{NMR}\left(\mathrm{CDCl}_{3}\right) \delta$ (ppm): 2.80-3.0 (m, 2H, C4-H), 3.46 (t, J=6.0 $\left.\mathrm{Hz}, 2 \mathrm{H}, \mathrm{CH}_{2} \mathrm{CH}_{2} \mathrm{Cl}\right), 3.67(\mathrm{t}, \mathrm{J}=6.1 \mathrm{~Hz}, 2 \mathrm{H}$, $\left.\mathrm{CH}_{2} \mathrm{CH}_{2} \mathrm{Cl}\right), 4.60(\mathrm{~m}, 1 \mathrm{H}, \mathrm{C} 5-\mathrm{H}), 5.80(\mathrm{~m}, 3 \mathrm{H}$,

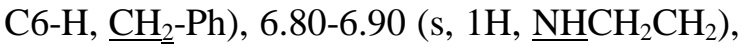
7.3 (s, 1H, C2-H), 7.87-8.1 (dd, J=7.0 Hz, 4H, ArH), 10.26 (s, 1H, NHCO).

Chemical oxidation of the 1,4-dihydropyridine derivatives by hydrogen peroxide

The respective 1,4-dihydropyridine derivative $(0.1 \mathrm{mmol})$ was added to $30 \%$ hydrogen peroxide $(2 \mathrm{~mL})$. The mixture was stirred and samples were monitored by HPLC to follow the formation of the quaternary products. Acetonitrile (10\% in $0.2 \%$ acetic acid solution) was used as mobile phase, flow rate $1.5 \mathrm{~mL} / \mathrm{min}$ and UV detector was used at $\lambda_{\max }$ $262 \mathrm{~nm}$. The apparent pseudo first-order rate constants of appearance of quaternary ( $\mathrm{k}$ app., $\mathrm{min}^{-1}$ ) were determined from linear regression analysis of $\ln$ AUC against time in minutes.

\section{Kinetics of oxidation of the 1,4-dihydro- pyridine derivatives in $20 \%$ brain homogenate}

About four grams of rat brain was taken, washed with ice-cold saline solution, and homogenized in a tissue homogenizer with about $20 \mathrm{~mL}$ of aqueous ice cold isotonic phosphate buffer $(0.2 \mathrm{M}, \mathrm{pH}$ 7.4), while keeping the homogenizer tube in an ice bath. To $5 \mathrm{~mL}$ of the freshly prepared brain homogenate, previously equilibrated at $37 \pm 1{ }^{\circ} \mathrm{C}$ in a water bath for 5 minutes, $300 \mu \mathrm{L}$ of 0.2 mmol methanolic solution of freshly prepared compounds IIIa-e was added. The mixture was kept at $37 \pm 1^{\circ} \mathrm{C}$ during the experiment. Samples of $0.5 \mathrm{~mL}$ were withdrawn from the tested mixture at different time intervals $(10,30,60$, 90, 120, and 160 minutes) and immediately added to $2 \mathrm{~mL}$ ice cold methanol, vortexed, and placed in the deep freezer $\left(-20^{\circ} \mathrm{C}\right)$. When all the samples have been collected, they were centrifuged at $4000 \mathrm{rpm}$ for 10 minutes, and the supernatants were analyzed by HPLC for their content of the dihydro-compounds and their corresponding quaternary derivatives. The apparent pseudo first-order rate constants of appearance of quaternary $\left(\mathrm{k}_{\mathrm{app}}, \min ^{-1}\right)$ were determined from linear regression analysis of ln AUC against time in minutes.

\section{Bioavailability study of 1,4-dihydropyridine derivatives}

Six groups, each of three Sprague Dawley female rats of average weight of 120-140 g were anesthetized with urethane. The freshly prepared solution of compound IIIa at a concentration of $25 \mathrm{mg} / \mathrm{mL}$ in dimethylsulfoxide (DMSO) was injected through the external jugular vein at a dose level of 30 $\mathrm{mg} / \mathrm{kg}$ of body weight. At appropriate time intervals $(10,30,60,90,120$, and 160 minutes), $1 \mathrm{~mL}$ blood was withdrawn from the eye and added immediately to a centrifuge tube containing $4 \mathrm{~mL}$ of acetonitrile. The animal was then decapitated, and the brain was collected, weighed, and kept frozen together with the blood samples. The whole brain was homogenized in $1 \mathrm{~mL}$ of water and mixed with $4 \mathrm{~mL}$ of $5 \%$ DMSO in acetonitrile. Both brain and blood samples were homogenized again and centrifuged at $4000 \mathrm{rpm}$ for 10 minutes. The supernatants from both brain and blood samples were analyzed by HPLC. Control tests were performed on six (one for every test time) Sprague Dawley female rats injected with DMSO at a dose of $1 \mathrm{~mL} / \mathrm{kg}$ animal weight and treated similarly as experiment.

\section{Colorimetric evaluation of alkylating activitiy of the prepared quaternary compounds IIa-e}

Methyl ethyl ketone (M \& B) and acetone AR (Merck) were used as solvents. 4-(4Nitrobenzyl) pyridine (NBP) was freshly recrystallized from cyclohexane and used as $5 \%$ solution in methyl ethyl ketone. Triethylamine was used as $17 \% \mathrm{w} / \mathrm{v}$ solution in acetone. Chlorambucil was obtained by extraction with acetone from leukeran tablets (Wellcome) and was used as the reference drug. The intensity of the purple colors produced in the test was measured on a Shimadzu UV 120-02 spectrophotometer. The apparent pseudo first-order rate constants of appearance of quaternary $\left(\mathrm{k}_{\text {app. }}, \mathrm{min}^{-1}\right)$ were determined from linear regression analysis of ln absorbance against time in minutes. 


\section{Method}

To a solution of the quaternary alkylating agents IIa-e $(10 \mathrm{mg})$ in methyl ethyl ketone (5 $\mathrm{mL}), 4-(4-$ nitrobenzyl) pyridine reagent $(5 \mathrm{~mL}$ of 5\% in methyl ethyl ketone) and water (1 $\mathrm{mL}$ ) were added. The mixture was then heated to $79^{\circ} \mathrm{C}$ in water bath. $1.5 \mathrm{~mL}$ were withdrawn from the reaction mixture at different time interval $(5,10,15,20,25,30 \mathrm{~min})$ cooled for one minute in an ice bath. Triethylamine reagent $(1.5 \mathrm{~mL})$ was added and mixed. The intensity of the purple color formed was measured within 2 minutes at the $\lambda_{\max } 560 \mathrm{~nm}$ against the reagent as blank. Chlorambucil (10 $\mathrm{mg}$ ) in methyl ethyl ketone ( $5 \mathrm{~mL}$ ) was used as reference drug to compare its activity under the same conditions with the activity of the tested compounds.

\section{Molecular docking}

All the molecular modeling studies were carried out on Intel Pentium 1.6 GHZ processor, $512 \mathrm{MB}$ memory with Windows XP operating system using Molecular Operating Environment (MOE 2008-10 Chemical Computing Group, Canada) ${ }^{16}$ as the computational software. All minimizations were performed with MOE until a RMSD gradient of $0.05 \mathrm{kcal}$ and $\mathrm{A}^{-1}$ with MMFF94X force-field and the partial charges were automatically calculated.

Crystal structure of the complex of tubulin-colchicine: stathmin-like domain was recovered from the Brookhaven Protein Data Bank (http:/www.rcsb.org/pdb/with the entry code 1SA0).

Colchicine was extracted from model and CEU were merged into the colchicine binding site in such a way that (2-chloroethyl) urea moiety was adjacent to the CBS.

The enzyme was prepared for docking studies where (i) Ligand molecule was removed from the enzyme active site. (ii) Hydrogen atoms were added to the structure with their standard geometry. (iii) MOE Alpha Site Finder was used for the active sites search in enzyme structure and dummy atoms were created from the obtained alpha spheres. (iv)The obtained model was then used in predicting the ligand-enzyme interactions at the active site.

A 3-D model was built to correlate the activity with the structure to design new and more active CEU derivatives.
The interactions obtained between CEU and the CBS, and the mean distances between the carbon atom bearing the chlorine atom of CEU (electrophile) and the carboxyl of Glu$\beta 198$ (nucleophile) were measured to evaluate the minimal distance required to initiate the nucleophilic reaction. As illustrated in Table (5), the distances between the heteroatoms of CEU and the amino acids of $\beta$-tubulin were calculated and were taken as a mode of stabilization, and the lowest energy scores of the docking of the CEU complex were used to describe the molecular stabilization of the CEU-CBS complexes. It is postulated that the distance and the ligand position are important parameters involved in the initiation or not of the acylation of Glu- $\beta 198$.

Concomitantly, the urea moiety anchors the drug to Cys- $\beta 239$ through a hydrogen bond locking the CEU in a spatial conformation favoring the nucleophilic addition. The latter hydrogen bond favors also the electronic induction of the 2-chloroethylamino group by decreasing the energy requirements for the acylation. Then, the acylation occurs between the carboxyl group of Glu- $\beta 198$ and the carbon atom (electrophilic) bearing the chlorine atom of CEU. Finally the acylation of Glu- $\beta 198$ leads to important conformational changes of the $\alpha, \beta$-tubulin heterodimer that is possibly in the same order of magnitude as the ones described with the Glu- $\beta 198$-Gly mutation ${ }^{17-21}$.

\section{RESULTS AND DISCUSSION}

\section{A- Chemistry}

A synthetic strategy was adopted as described in Scheme 1 to obtain the final target compounds, 1-(2-chloroethyl)-3-[1-alkyl(4substituted benzyl)-1,4-dihydropyridin-3-yl]urea (IIIa-e). Compound I was synthesized through reaction of 3-aminopyridine with 2chloroethylisocyanate in THF. Direct quaternization of 1-(2-chloroethyl)-3-pyridin-3yl urea (I) with appropriate alkyl (4-substituted benzyl) halides gave compounds (IIa-e). The obtained quaternary compounds were reduced using sodium dithionite in alkaline medium to give the corresponding dihydropyridines (IIIae) in analogy to the reported procedures ${ }^{22 \& 23}$.

The structures of the compounds IIa-e were confirmed by their elemental microanalyses, UV, IR and ${ }^{1} \mathrm{H}-\mathrm{NMR}$ data. 


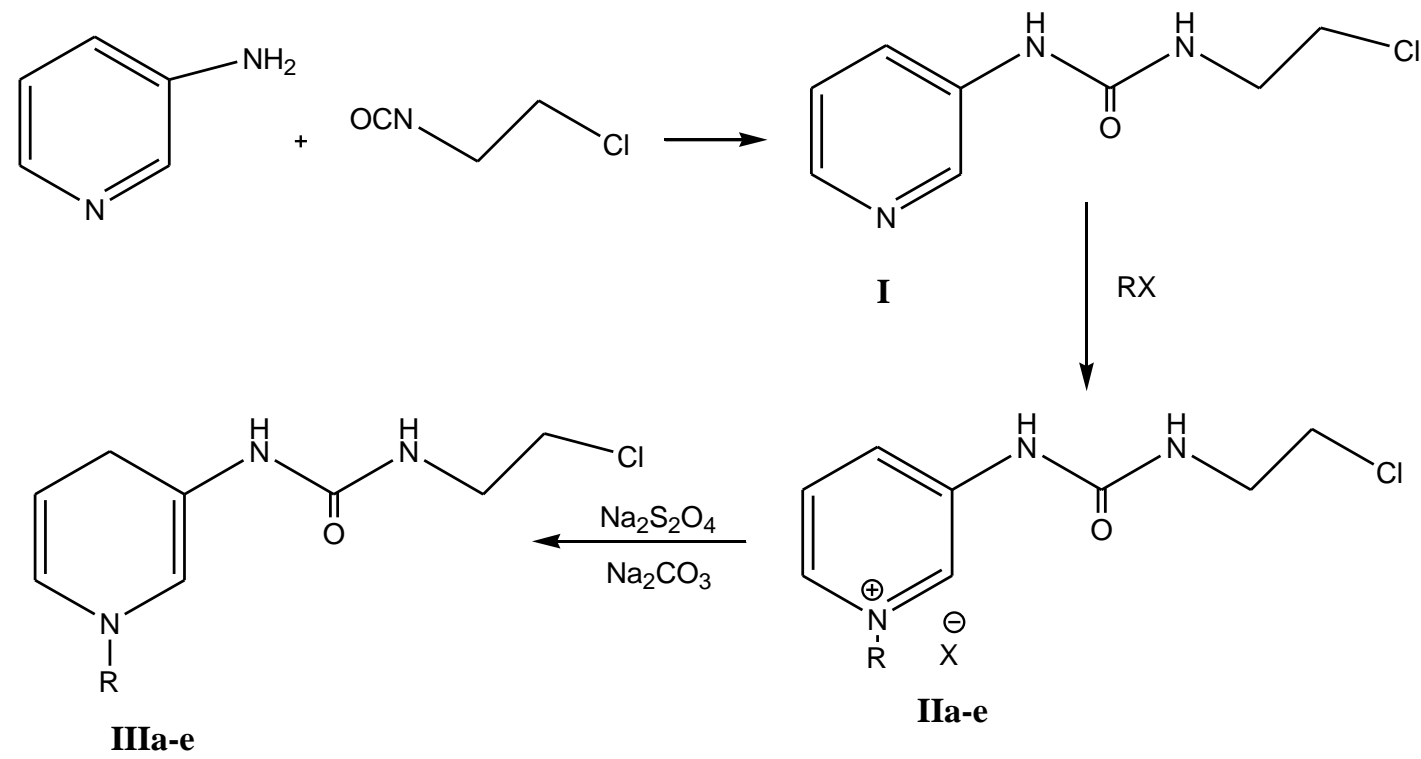

$\mathrm{R}, \mathrm{X}$; a: $\mathrm{CH}_{3}, \mathrm{I} ; \mathbf{b}: \mathrm{C}_{2} \mathrm{H}_{5}$, I; c: $-\mathrm{CH}_{2}-\mathrm{C}_{6} \mathrm{H}_{4}(4-\mathrm{Cl}), \mathrm{Cl}$; d:- $\mathrm{CH}_{2}-\mathrm{C}_{6} \mathrm{H}_{4}(4-\mathrm{Br}), \mathrm{Br}$; e:- $\mathrm{CH}_{2}-\mathrm{C}_{6} \mathrm{H}_{4}\left(4-\mathrm{NO}_{2}\right), \mathrm{Br}$

Scheme 1: Synthesis of the target compounds IIa-e and IIIa-e.

Structures of the 1,4-dihydropyridines IIIa-e were established by their ${ }^{1} \mathrm{H}-\mathrm{NMR}$ and UV spectra which show absorption maxima at 348-366 nm characteristic for the 1,4-dihydropyridine derivatives ${ }^{22 \& 23}$.

\section{B- Chemical and biological investigation}

The prepared 1,4-dihydropyridine derivatives were subjected to various chemical and biological investigations to evaluate their ability to cross the BBB, and to be oxidized biologically into their corresponding quaternary compounds. HPLC analyses has been applied to monitor the oxidation of the tested 1,4-dihydropyridines into their corresponding quaternary compounds. The HPLC analyses showed that the 1,4dihydropyridines were detected in blood and brain homogenate at retention time of 5.1-5.6 min while the quaternaries were detected at retention time of 6.2-6.5 min. The mean calibration curve was plotted and best-fit linear regression equation was derived, and used to estimate the concentrations of the quaternary salts.

Hydrogen peroxide oxidizes the dihydropyridines by free radical mechanism. The increase in concentration of the quaternary compounds were monitored by HPLC using UV detector at $\lambda_{\max } 262 \mathrm{~nm}$. The results in Table (1) indicate the ease of oxidation of 1-methyl-1,4-dihydropyridine IIIa to the corresponding quaternary IIa with high oxidation rate $\left(\mathrm{K}_{\mathrm{app}} 17.54 \times 10^{-2}\right)$. The substituted 1-benzyl-1,4-dihydropyridines (IIIc-e) converted to the corresponding quaternaries IIc-e with oxidation rates (three to four fold) less than IIIa $\left(\mathrm{K}_{\text {app }} 6.52,6.90,4.42 \times 10^{-2}\right.$ respectively). The 1-(4-nitrobenzyl)-1,4dihydropyridinyl-3-chloroethylurea IIIe exhibits the lowest rate of oxidation. The electron withdrawing effect of the nitro group decreases the electron density on the ring nitrogen of 1,4-dihydropyridine more than the corresponding bromo and chloro derivatives.

Table 1: Kinetics of oxidation of the 1,4dihydropyridine derivatives IIIa-e with hydrogen peroxide.

\begin{tabular}{||c|c|c|c||}
\hline $\begin{array}{c}\text { Compound } \\
\text { No. }\end{array}$ & $\begin{array}{c}\mathrm{K}_{\text {app }} \min ^{-1} \\
\times 10^{-2}\end{array}$ & $\begin{array}{c}\mathrm{t}_{1 / 2} \\
(\mathrm{~min})\end{array}$ & $\mathrm{r}$ \\
\hline IIIa & 17.54 & 3.9 & 0.968 \\
\hline IIIb & 14.31 & 4.8 & 0.979 \\
\hline IIIc & 6.52 & 10.6 & 0.990 \\
\hline IIId & 6.90 & 10.0 & 0.990 \\
\hline IIIe & 4.42 & 15.7 & 0.980 \\
\hline
\end{tabular}

$\mathrm{K}_{\text {app }}$ is the apparent pseudo first order rate constant of appearance of quaternary derivatives, $t_{1 / 2}$ is the half-time of the reaction, $r=$ correlation coefficient. 
The enzymatically oxidation of the prepared 1,4-dihydropyridine derivatives in the brain could be predicted by spiking the test compounds in brain homogenate. The data summarized in Table (2) indicates facile oxidation of 1-methyl-1,4-dihydropyridine derivative IIIa into corresponding quaternary IIa with high oxidation rate $\left(\mathrm{K}_{\mathrm{app}}=42.63 \times 10^{-2}\right.$, $\left.\mathrm{t}_{1 / 2} 1.6 \mathrm{~min}\right)$. The 4-substituted benzyl-1,4dihydropyridines IIIc-e converted to the corresponding quaternaries IIc-e with oxidation rates (seven to twelfth fold) less than IIIa ( $\mathrm{K}_{\text {app }} 6.56,4.74,3.55 \times 10^{-2}$ respectivelly). Compounds IIIa-e exhibited similar behavior as in case of the chemical oxidation.

Table 2: kinetics of oxidation of the 1,4dihydropyridine derivatives IIIa-e in brain homogenate.

\begin{tabular}{|c|c|c|c||}
\hline $\begin{array}{c}\text { Compd. } \\
\text { No. }\end{array}$ & $\begin{array}{c}\text { Brain homogenate } \\
\mathrm{K}_{\text {app }} \min ^{-1} \times 10^{-2}\end{array}$ & $\begin{array}{c}\mathrm{t}_{1 / 2} \\
(\mathrm{~min})\end{array}$ & $\mathrm{r}$ \\
\hline IIIa & 42.63 & 1.6 & 0.994 \\
\hline IIIb & 34.82 & 2.0 & 0.989 \\
\hline IIIc & 6.56 & 10.6 & 0.986 \\
\hline IIId & 4.74 & 14.6 & 0.980 \\
\hline IIIe & 3.55 & 19.5 & 0.990 \\
\hline
\end{tabular}

$\mathrm{K}_{\mathrm{app}}$ is the apparent pseudo first order rate constant of appearance of quaternary derivatives, $t_{1 / 2}$ is the half-time of the reaction, $r=$ correlation coefficient.

Compound IIIa was selected for in-vivo study due to its ease of chemical and enzymatic oxidation. A dose of $30 \mathrm{mg} / \mathrm{kg}$, was injected to rats and at selected time intervals, blood and the brain samples were collected. The concentrations of the quaternary derivative IIa, was measured in both blood sample and brain homogenate using HPLC assay. The results are given in Table (3).

Table 3: In-vivo distribution of IIIa in blood $(\mathrm{mg} / \mathrm{mL})$ and (brain homogenate $(\mathrm{mg} / \mathrm{g})$ in rats.

\begin{tabular}{||c|c|c|}
\hline \multirow{2}{*}{ Time (min) } & \multicolumn{2}{|c|}{ Mean conc. } \\
\cline { 2 - 3 } & Blood & Brain \\
\hline 10 & $75.7 \pm 6.2$ & $18.5 \pm 1.8$ \\
\hline 30 & $56.3 \pm 5.4$ & $20.3 \pm 2.1$ \\
\hline 60 & $34.9 \pm 3.3$ & $27.2 \pm 2.6$ \\
\hline 90 & $20.1 \pm 1.2$ & $56.4 \pm 5.4$ \\
\hline 120 & - & $33 \pm 4.2$ \\
\hline 160 & - & $7.62 \pm 0.9$ \\
\hline
\end{tabular}

The analyses of blood samples after 10 minutes proved the presence of compound IIa in high concentration. The concentration declined rapidly in blood and undetected after $90 \mathrm{~min}$. The picture looked different in the brain samples. The concentration of IIa increased steadily in the brain, and reach its maximum at $90 \mathrm{~min}$ followed by decline indicating the sustained release of the quaternary compound.

\section{Determination of the alkylating potential}

The alkylating potential of the prepared compounds IIa-e were evaluated colorimetrically using NBP as analytical reagent ${ }^{24-26}$. NBP reacts with alkylating agents and gives a purple color on alkalinization (Fig. 1). The intensity of the produced color is directly proportional to the degree of alkylation. Chlorambucil was used as a reference. All of the tested compounds proved to be active alkylating agents as shown in Table (4). The p-nitrobenzyl substituted derivative IIe was the most active member among this series, with alkylating activity $\left(\mathrm{K}_{\mathrm{app}}=0.219 \mathrm{~min}^{-1}, \mathrm{t}_{1 / 2}=3.2 \mathrm{~min}\right)$ comparable to that of chlorambucil $\left(\mathrm{K}_{\mathrm{app}}=0.192 \mathrm{~min}^{-1}, \mathrm{t}_{1 / 2}=4.9\right.$ min).

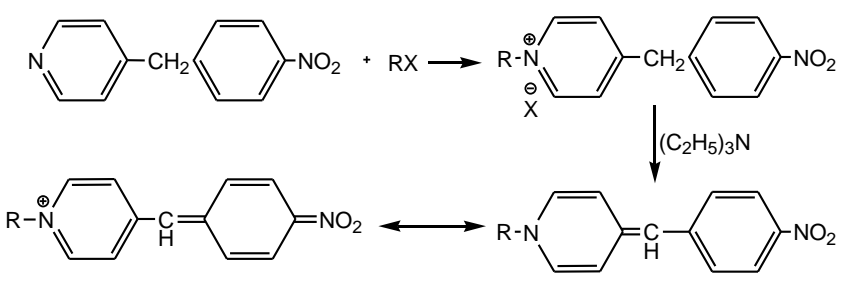

Fig. 1: Reaction of alkylating agents with NBP reagent.

Table 4: Alkylating activity of compounds I and IIa-e.

\begin{tabular}{|l|l|c|c|c|c||}
\hline \multirow{2}{*}{$\begin{array}{c}\text { Compd. } \\
\text { No. }\end{array}$} & \multirow{2}{*}{$\mathrm{R}$} & \multirow{2}{*}{$\mathrm{x}$} & \multicolumn{3}{|c|}{ Regression data } \\
\cline { 4 - 6 } & & & $\mathrm{K}_{\mathrm{app}}$ & $\mathrm{t}_{1 / 2}$ & $\mathrm{r}$ \\
\hline I & $\mathrm{H}$ & - & 0.032 & 21.7 & 0.999 \\
\hline IIa & $\mathrm{CH}_{3}$ & $\mathrm{I}$ & 0.041 & 16.5 & 0.998 \\
\hline IIb & $\mathrm{C}_{2} \mathrm{H}_{5}$ & $\mathrm{I}$ & 0.053 & 13.0 & 0.999 \\
\hline IIc & $\mathrm{p}-\mathrm{Cl}_{-} \mathrm{C}_{6} \mathrm{H}_{4}-\mathrm{CH}_{2^{-}}$ & $\mathrm{Cl}$ & 0.125 & 5.5 & 0.999 \\
\hline IId & $\mathrm{p}-\mathrm{Br}_{-} \mathrm{C}_{6} \mathrm{H}_{4}-\mathrm{CH}_{2-}$ & $\mathrm{Br}$ & 0.178 & 4.0 & 0.999 \\
\hline IIe & $\mathrm{P}_{-} \mathrm{NO}_{2}-\mathrm{C}_{6} \mathrm{H}_{4}-\mathrm{CH}_{2^{-}}$ & $\mathrm{Br}$ & 0.219 & 3.2 & 0.987 \\
\hline Chlorambucil & 0.192 & 4.9 & 0.994 \\
\hline
\end{tabular}

Each reading was triplicate, reaction temp. $79^{\circ} \mathrm{C}$, $\lambda_{\text {max }}=560 \mathrm{~nm}$. 


\section{Molecular modeling study}

Based on the hypothesis brought about by the X-ray structure by Ravelli ${ }^{20}$, showing that the tubulin-colchicine complex is compatible with acylation (alkylation through ester formation) of Glu- $\beta 198$ by $\mathrm{CEU}^{17}$. Molecular modeling study was carried out using MOE on CEU structure. These studies were intended to develop novel CEU that would be more active and more selective toward the Glu- $\beta 198$ residue imbedded in the colchicine-binding site. The synthesized series of CEU derivatives IIa-e and IIIa-e were selected for molecular modeling study using crystal structure of tubulin-colchicine complex. The biological activity is expressed in terms of the alkylating potentials using NBP.

Docking studies were performed by MOE using crystal structure of the complex of tubulin-colchicine: stathmin-like domain (recovered from the Brookhaven Protein Data Bank; http:/www.rcsb.org/pdb/with the entry code 1SA0). Fifty docking interactions for each ligand and the top-scoring configuration of each of the ligand-enzyme complexes was selected on energetic grounds.

In this study, the analyses were based on the position of the ligand and the nature of the interactions occurring into the pocket with CEU, which are more important for the acylation of Glu- $\beta 198$. All models are showing that the 2-chloroethylurea moiety of CEU is protruding inside the adjacent pocket toward
Glu- $\beta 198$ in such a way that the acylation is favored. Cys- $\beta 239$ is probably one of the most important amino acid residue involved in the stabilization of the CEU-tubulin complex prior to the acylation of Glu- $\beta 198$.

It is also important to note that all models of the CEU-tubulin complexes show hydrogen bonds interactions between the $\mathrm{SH}$ group of Cys- $\beta 239$ and the $\mathrm{C}=\mathrm{O}$ and $\mathrm{NH}$ groups of urea moiety of CEU. In addition to vander-Walls interactions between substituent on pyridine ring and CBS. These interactions probably lock the 2-chloroethylurea moiety into the pocket containing Glu- $\beta 198$. The distance between the urea moiety of CEU and the SH group of the binding site is an important parameter favoring Glu- $\beta 198$ acylation. As shown from Table (5), the above mentioned distances ranging from (3.04-3.61 $\mathrm{A}^{\circ}$ ) for quaternary compounds IIa-e and (2.53-6.09 $\left.\mathrm{A}^{\circ}\right)$ for dihydropyridine compounds IIIa-e. The ideal distance range from $\left(2.4-3.5 \mathrm{~A}^{\circ}\right)^{17}$ which is in agreement with this result. The shorter the distance between the electrophilic group of $\mathrm{CEU}$ and the $-\mathrm{COOH}$ of Glu- $\beta 198$ is, the higher the rate of acylation. This distances range from $\left(5.77-7.82 \mathrm{~A}^{\circ}\right)$ for quaternary compounds IIa-e, and (5.93 - 9.64 $\mathrm{A}^{\circ}$ ) for dihydropyridine compounds IIIa-e. As shown from Table (5) and Figure (2), compound IIe exhibit the shortest distance of all tested compounds which is in agreement with its alkylating potential using NPB.

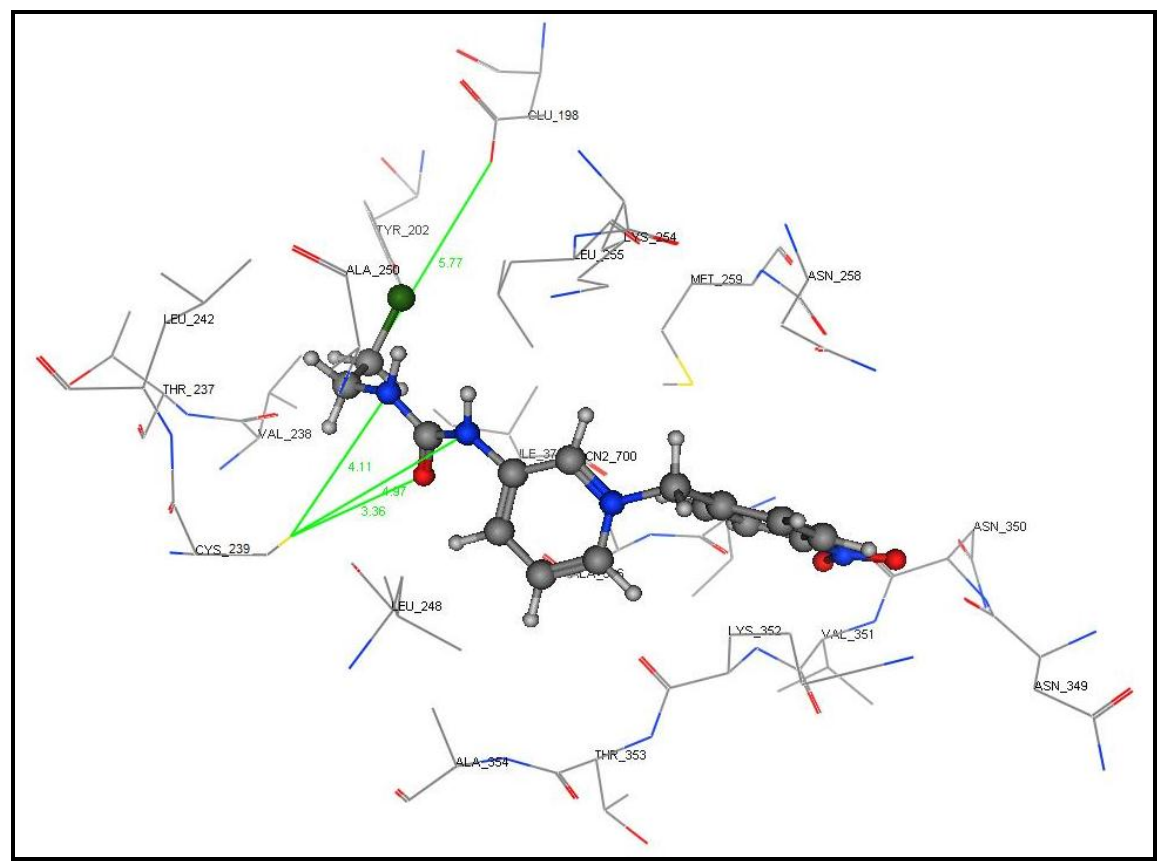

Fig. 2: 3D docked structure of IIe (ball and stick) at Tubulin-Colchicine active site. 
Table 5: Docking scores and distances $\left(\mathrm{A}^{\circ}\right)$ between heteroatoms of the key amino acids and the CEU in ten different CEU models.

\begin{tabular}{|c|c|c|c|c|c|}
\hline $\begin{array}{l}\text { Compd. } \\
\text { No. }\end{array}$ & $\begin{array}{l}\text { Lower } \\
\text { energy } \\
\text { score }\end{array}$ & $\begin{array}{l}\text { CEU interacting } \\
\text { group }\end{array}$ & $\begin{array}{c}\text { Amino acid } \\
\text { involved }\end{array}$ & $\begin{array}{l}\text { Amino acid } \\
\text { interacting } \\
\text { group }\end{array}$ & $\begin{array}{l}\text { Interatomic } \\
\text { distance }\left(\mathrm{A}^{\circ}\right)\end{array}$ \\
\hline IIa & -8.0242 & $\begin{array}{l}\mathrm{C}=\mathrm{O} \text { (urea) } \\
\mathrm{NH} \text { (urea) } \\
\mathrm{C}-\mathrm{Cl}\end{array}$ & $\begin{array}{l}\text { Cys- } \beta 239 \\
\text { Cys- } \beta 239 \\
\text { Glu- } \beta 198\end{array}$ & $\begin{array}{c}\mathrm{SH} \\
\mathrm{SH} \\
\mathrm{O}-\mathrm{C}=\mathrm{O}\end{array}$ & $\begin{array}{l}3.20 \\
4.17 \\
7.11\end{array}$ \\
\hline IIb & -7.7477 & $\begin{array}{l}\mathrm{C}=\mathrm{O} \text { (urea) } \\
\mathrm{NH} \text { (urea) } \\
\mathrm{C}-\mathrm{Cl}\end{array}$ & $\begin{array}{l}\text { Cys- } \beta 239 \\
\text { Cys- } \beta 239 \\
\text { Glu- } \beta 198\end{array}$ & $\begin{array}{c}\mathrm{SH} \\
\mathrm{SH} \\
\mathrm{O}-\mathrm{C}=\mathrm{O}\end{array}$ & $\begin{array}{l}3.49 \\
3.65 \\
7.82\end{array}$ \\
\hline IIc & -8.5050 & $\begin{array}{l}\mathrm{C}=\mathrm{O} \text { (urea) } \\
\mathrm{NH} \text { (urea) } \\
\mathrm{C}-\mathrm{Cl}\end{array}$ & $\begin{array}{l}\text { Cys- } \beta 239 \\
\text { Cys- } \beta 239 \\
\text { Glu- } \beta 198\end{array}$ & $\begin{array}{c}\mathrm{SH} \\
\mathrm{SH} \\
\mathrm{O}-\mathrm{C}=\mathrm{O}\end{array}$ & $\begin{array}{l}3.61 \\
3.52 \\
5.89 \\
\end{array}$ \\
\hline IId & -9.2048 & $\begin{array}{l}\mathrm{C}=\mathrm{O} \text { (urea) } \\
\mathrm{NH} \text { (urea) } \\
\mathrm{C}-\mathrm{Cl}\end{array}$ & $\begin{array}{l}\text { Cys- } \beta 239 \\
\text { Cys- } \beta 239 \\
\text { Glu- } \beta 198 \\
\end{array}$ & $\begin{array}{c}\mathrm{SH} \\
\mathrm{SH} \\
\mathrm{O}-\mathrm{C}=\mathrm{O}\end{array}$ & $\begin{array}{l}3.04 \\
4.42 \\
5.89 \\
\end{array}$ \\
\hline IIe & -8.9546 & $\begin{array}{l}\mathrm{C}=\mathrm{O} \text { (urea) } \\
\mathrm{NH} \text { (urea) } \\
\mathrm{C}-\mathrm{Cl}\end{array}$ & $\begin{array}{c}\text { Cys- } \beta 239 \\
\text { Cys- } \beta 239 \\
\text { Glu-198 }\end{array}$ & $\begin{array}{c}\mathrm{SH} \\
\mathrm{SH} \\
\mathrm{O}-\mathrm{C}=\mathrm{O}\end{array}$ & $\begin{array}{l}3.36 \\
4.54 \\
5.77\end{array}$ \\
\hline IIIa & -7.3995 & $\begin{array}{l}\mathrm{C}=\mathrm{O} \text { (urea) } \\
\mathrm{NH} \text { (urea) } \\
\mathrm{C}-\mathrm{Cl}\end{array}$ & $\begin{array}{l}\text { Cys- } \beta 239 \\
\text { Cys- } \beta 239 \\
\text { Glu- } \beta 198\end{array}$ & $\begin{array}{c}\mathrm{SH} \\
\mathrm{SH} \\
\mathrm{O}-\mathrm{C}=\mathrm{O}\end{array}$ & $\begin{array}{l}4.55 \\
5.91 \\
7.74\end{array}$ \\
\hline IIIb & -7.6120 & $\begin{array}{l}\mathrm{C}=\mathrm{O} \text { (urea) } \\
\mathrm{NH} \text { (urea) } \\
\mathrm{C}-\mathrm{Cl}\end{array}$ & $\begin{array}{l}\text { Cys- } \beta 239 \\
\text { Cys- } \beta 239 \\
\text { Glu- } \beta 198\end{array}$ & $\begin{array}{c}\mathrm{SH} \\
\mathrm{SH} \\
\mathrm{O}-\mathrm{C}=\mathrm{O}\end{array}$ & $\begin{array}{l}6.09 \\
5.63 \\
9.64 \\
\end{array}$ \\
\hline IIIc & -7.8666 & $\begin{array}{l}\mathrm{C}=\mathrm{O} \text { (urea) } \\
\mathrm{NH} \text { (urea) } \\
\mathrm{C}-\mathrm{Cl}\end{array}$ & $\begin{array}{c}\text { Cys- } \beta 239 \\
\text { Cys- } \beta 239 \\
\text { Glu-198 } \\
\end{array}$ & $\begin{array}{c}\mathrm{SH} \\
\mathrm{SH} \\
\mathrm{O}-\mathrm{C}=\mathrm{O}\end{array}$ & $\begin{array}{l}2.53 \\
1.73 \\
7.06 \\
\end{array}$ \\
\hline IIId & -9.5689 & $\begin{array}{l}\mathrm{C}=\mathrm{O} \text { (urea) } \\
\mathrm{NH} \text { (urea) } \\
\mathrm{C}-\mathrm{Cl}\end{array}$ & $\begin{array}{l}\text { Cys- } \beta 239 \\
\text { Cys- } \beta 239 \\
\text { Glu- } \beta 198\end{array}$ & $\begin{array}{c}\mathrm{SH} \\
\mathrm{SH} \\
\mathrm{O}-\mathrm{C}=\mathrm{O}\end{array}$ & $\begin{array}{l}2.76 \\
3.89 \\
7.23\end{array}$ \\
\hline IIIe & -9.2957 & $\begin{array}{l}\mathrm{C}=\mathrm{O} \text { (urea) } \\
\mathrm{NH} \text { (urea) } \\
\mathrm{C}-\mathrm{Cl}\end{array}$ & $\begin{array}{l}\text { Cys- } \beta 239 \\
\text { Cys- } \beta 239 \\
\text { Glu- } \beta 198\end{array}$ & $\begin{array}{c}\mathrm{SH} \\
\mathrm{SH} \\
\mathrm{O}-\mathrm{C}=\mathrm{O}\end{array}$ & $\begin{array}{l}2.74 \\
3.00 \\
5.93\end{array}$ \\
\hline
\end{tabular}

\section{Conclusion}

We can concluded that in-vitro oxidation studies showed the ability of the tested dihydropyridine derivatives (IIIa-e) to be oxidized into the corresponding quaternary compounds (IIa-e). The rate of oxidation was affected by substitution on nitrogen of pyridine nucleus. The 4-nitrobenzyl group optimized the rate of oxidation to ensure the delivery of the drug into the brain and sustained release of the quaternary compound. In-vitro studies showed good alkylating potential of compound IIe comparable to reference standard, chlorambucil. The in-vivo studies revealed that 1,4-dihydropyridines, could cross the BBB at detectable concentrations.

\section{REFERENCES}

1- E. Mounetou, J. Legault, J. Lacroix, and R. C. Gaudreault, J. Med. Chem., 44, 694 (2001).

2- N. Bodor and H. H. Farag, ibid., 26, 528 (1983). 
3- N. Bodor and H. H. Farag, J. Pharm. Sci., 73, 385 (1984).

4- V. A. Levin and C. B. Wilson, Cancer Treat. Rep., 60, 719 (1976).

5- K. S. Raghavan, E. Shek, and N. Bodor, Anticancer Drug Des., 2, 25 (1987).

6- A. A. Simkula and S.H. Yalkowsty, J. Pharm. Sci., 64, 181 (1975).

7- N. Bodor, H. Farag, M. D. C. Barros and W. M. Wu. P. Buchwald, J. Drug Target, 10, 63 (2002).

8- M. A. El-Sherbeny, H. S. Al-Salem, M. A. Sultan, M. A. Radwan, H. H. Farag and H. I. El-Subbagh, Arch. Pharm. Pharm. Med. Chem., 336, 445 (2003).

9- P. Calabresis, R. E. Parks, T. W. Rall and F. Murad in "Pharmacological Basis of Therapeutics", L. S. Goodman, A. Gilman, Eds; MacMilla; New York, 1985, p. 1240.

10- S. R. Rajski and R. M. Willimas, Chem. Rev., 98, 2723 (1998).

11. R. C. Gaudreault, M. A. Alaoui-Jamali, G. Batist, P. Be`chard, J. Lactrois, and P. Poyet, Cancer Chemother. Pharmacol., 33, 489 (1994).

12. J. Legault, J. F. Gaulin, E. Mounetou, S. Bolduc, J. Lacroix and P. Poyet, Cancer Res., 60, 985 (2000).

13. B. Bouchon, C. Chambon, E. Mounetou, J. Papon, E. Miot-Noirault and R. C. Gaudreault, Mol. Pharmacol., 68, 1415 (2005).

14. R. B. Ravelli, B. Gigant, P. A. Curmi, I. Jourdain, S. Lachkar and A. Sobel, Nature, 428, 198 (2004).
15. A. M. Crider, R. Lamey, H. G. Floss, J. M. Gassady and W. J. Bradner, J. Med. Chem., 23, 848 (1980).

16. Molecular Operating Environment (MOE), Version 2008-10, Chemical Computing Group, Inc., Montreal, Quebec, Canada, 2005. http://www.Chemcomp.Com.

17. S. Fortin, L. Wei., E. Moreau, P. labrie, É. Petitclerc, L. P. Kotra and R. C. Gaudreault, Bioorg. Med. Chem., 17, 3690 (2009).

18. S. Fortin, P. labrie, E. Moreau, L. Wei. L. P. Kotra and R. C. Gaudreault, ibid., 16, 1914 (2008).

19. J. S. Fortin, M. F. Côté, J. Lacroix, É. Petitclerc and R. C. Gaudreault, ibid., 16, 7477 (2008).

20. S. Fortin, E. Moreau, J. Lacroix, J. C. Teulade, A. Patenaude, R. C. L. Wei, L. P. Kotra and R. C. Gaudreault, Bioorg. Med. Chem. Lett., 17, 2000 (2007).

21. S. Fortin, E. Moreau, J. Lacroix, M. F. Côté, É. Petitclerc and R. C. Gaudreault, Eur. J. Med. Chem., (2010) in press.

22. O. M. Friedman, K. Pollak and E. Khedouri, J. Med. Chem., 6, 462 (1963).

23. G. Glankenhorn and E. Moore, J. Am. Chem. Soc., 102, 1092 (1980).

24. E. Koenigs, K. Koehler and R. Blindow, Ber., 58B, 933 (1925).

25. E. Epstein, N. Rosenthal and R. Ess, J. Anal. Chem., 27, 1435 (1955).

26. H. H. Farag, A. M. Abdel-Alim, M. M. ElGendy and N. A. El-Koussi, Bull. Pharm. Soc., Assiut University 16 (2), 141 (1993). 